\title{
Sacred Violence: When Ancient Egyptian Punishment was Dressed in Ritual Trappings
}

Kerry Muhlestein

Brigham Young University - Utah, kerry_muhlestein@byu.edu

Follow this and additional works at: https://scholarsarchive.byu.edu/facpub

Part of the Religion Commons

\section{Original Publication Citation}

Muhlestein, Kerry. "Sacred Violence: When Ancient Egyptian Punishment was Dressed in Ritual Trappings." Near Eastern Archaeology 78.4 (2015): 244-251.

\section{BYU ScholarsArchive Citation}

Muhlestein, Kerry, "Sacred Violence: When Ancient Egyptian Punishment was Dressed in Ritual Trappings" (2015). Faculty Publications. 1970.

https://scholarsarchive.byu.edu/facpub/1970

This Peer-Reviewed Article is brought to you for free and open access by BYU ScholarsArchive. It has been accepted for inclusion in Faculty Publications by an authorized administrator of BYU ScholarsArchive. For more information, please contact ellen_amatangelo@byu.edu. 


\section{SACRED VIOLENCE When Ancient Egyptian Punishment was Dressed in Ritual Trappings}

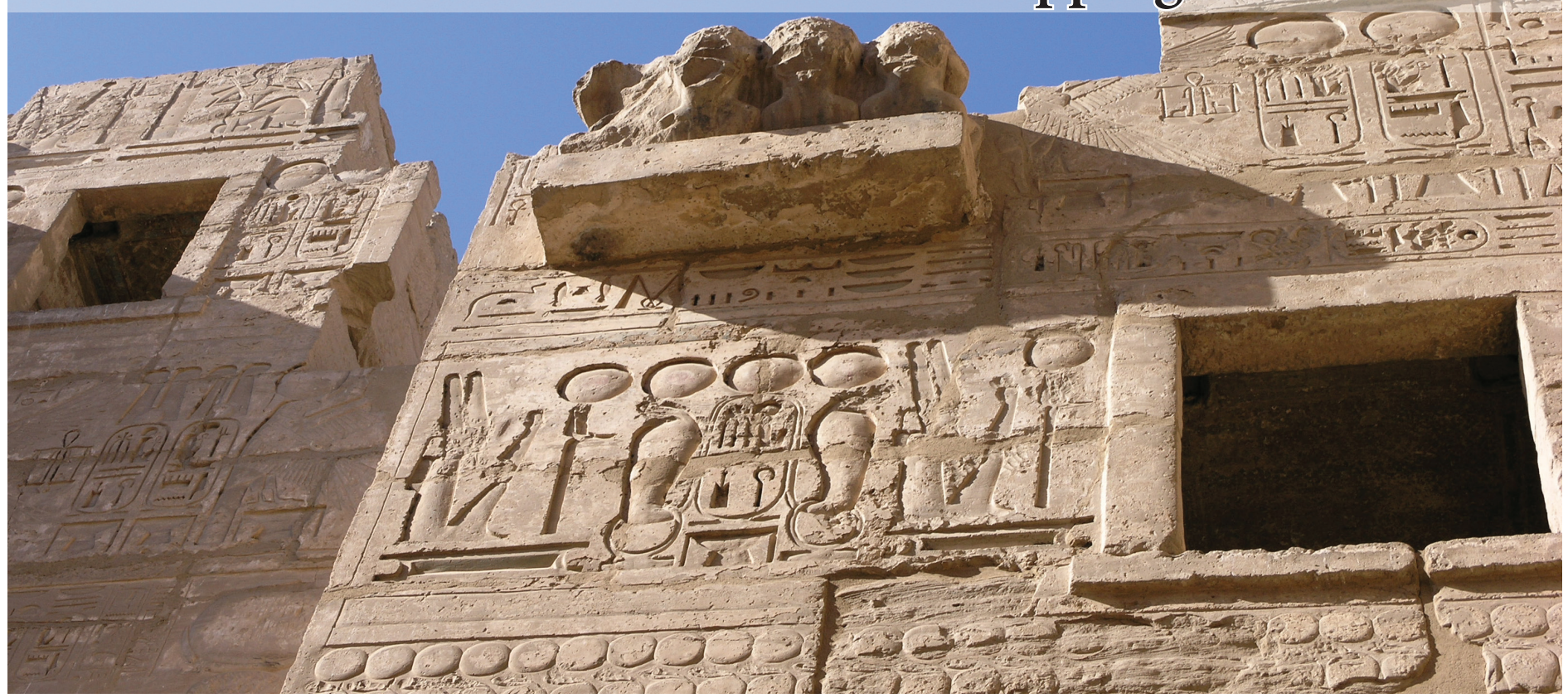

The migdol at Medinet Habu, where the king symbolically stepped on the heads of conquered or slain foreigners. Photograph by Kerry Muhlestein.

\section{Kerry Muhlestein}

$D$ espite gaping holes in our knowledge of ancient Egyptian laws and punishments, the sheer amount of data available for that long-lasting culture dictates that we limit our study of punishments both topically and temporally. This article will investigate the topic of ritual-associated killing from the Old Kingdom through the Libyan era. Earlier phases of Egyptian history yield evidence of ritual killing, such as the retainer burials associated with Early Dynastic kings or the labels of Aha and Djer (fig. 1), that seem to depict ritual slaughter. Whatever the nature of these seeming programs of ritual slaying, we cannot trace a continuation into the Old Kingdom. This does not mean they did not survive in some form, only that they are not attested clearly in the surviving sources. Additionally, for the time period under study there are almost certainly instances, and perhaps even programs, of sanctioned ritual violence that do not have a manifestation in the sources currently available to us. As a result, we cannot say what forms of ritual violence did not happen. Instead we will focus on looking for patterns in the available evidence for what did happen. Given the extant corpus, it appears that institutionally sanctioned ritual violence centered around two main ideas: interference with cult, and rebellion. Murder sometimes also elicited ritual punishment.
For the purposes of this article, we will consider an event to have ritual trappings if it mirrored that which was regularly experienced in Egyptian cultic activities. In other words, if the language used to describe an action matches the language used to describe cultic activity, or if an action took place in the same way it would in a cultic setting, we will consider that text or action to have ritual trappings. It is the similarity with known ritual activity that is of concern to us in this study. While the lack of ritually charged terminology does not mean that ritual trappings were not present, and thus we must be careful in assuming that there was no ritual aspect, if terminology or actions are employed that were routinely part of a ritual, we can be sure that a ritual aspect was intended.

\section{Ritual Violence Associated with Cult}

While we cannot rule out a regular program of ritual slaying at Egyptian temple complexes, the lack of evidence for it makes its existence doubtful. In contrast, there is evidence for ritual slaying as a result of interfering with temple cultic practices. The strongest case for this comes from an inscription attributed to Senusret I. While there are some questions about the textual history and propagandistic nature of this inscription (Buchberger 2006: 15-21), there is little doubt that it tells us of the kinds of violence that occurred in the Middle Kingdom (Muhlestein 2008: 191-193). Senusret claims to 
have found the temple of Tôd in a state of disrepair and desecration (fig. 2). The "guilty" parties were killed in a variety of ways, including flaying, beheading, and burning (Redford 1987: 42-43). The language of the inscription draws an intentional parallel with animal sacrifices. It states that these punishments were inflicted "as sacrifices (sm3yw)" (The Tod Inscription of Senusret: line $\mathrm{X}+32$ ), using a headless cow determinative that is always associated with a sacrifice, providing a clear ritual context. Despite debates over whether or not Senusret actually carried

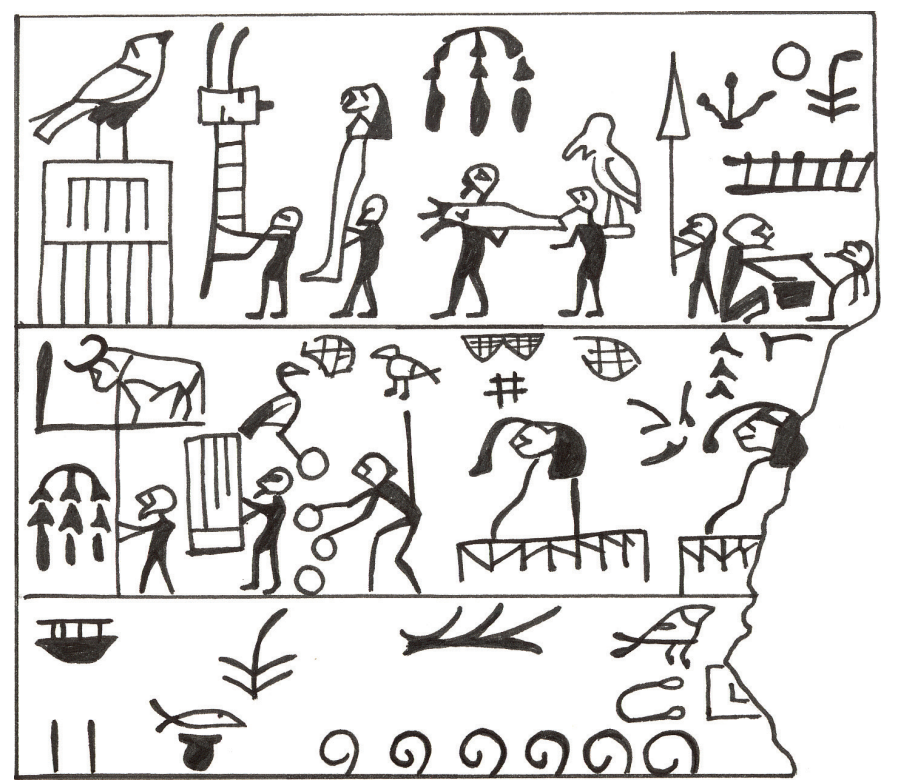

out all these punishments, the context from which the inscription sprang clearly represents a society that was familiar with ritual trappings associated with killing those who interfered with the cult.

On the other hand, there are many instances of interference with temple cult that were deemed a capital crime, but for which there is no evidence of ritual aspects to the punishment. In the $18^{\text {th }} \mathrm{Dy}$ nasty we learn of a scribe who had diverted corvee labor from the Temple of Thoth. He was warned that he should correct the situation or else "death is

Figure 1 (above). Reproduction of an ivory label of King Aha, depicting in the upper right corner what many consider to be a ritual slaying. Drawing by Daniel McClellan, courtesy of the Brigham Young University Ancient Near Eastern Studies Program.

Figure 2 (below). Ruins of the Temple of Tôd. Photograph by Olaf Tausch.

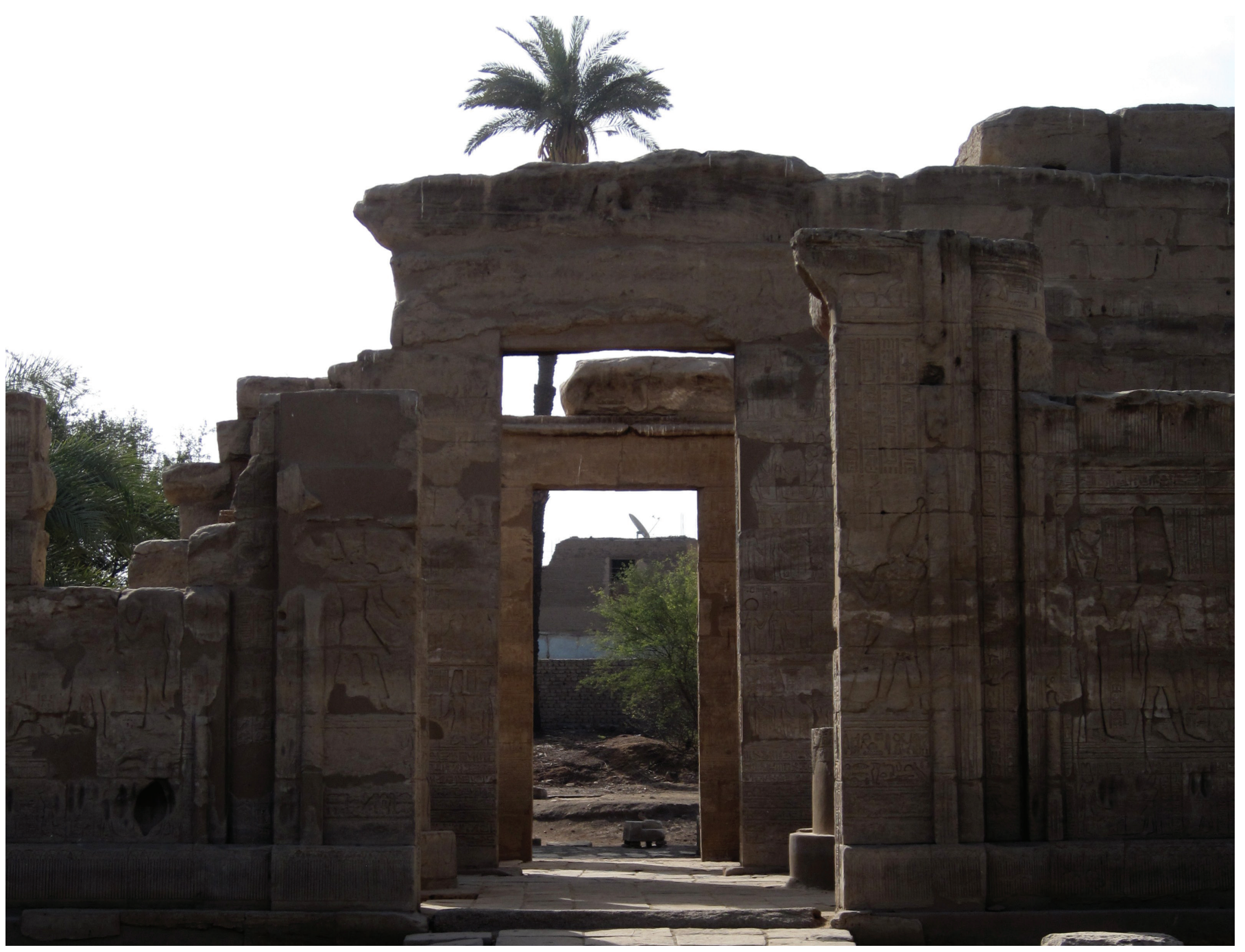


the way in which I am involved with you" (P. Turin: A, 4, 9-10). The scribe is also told that his actions make it seem as if "you wish to die rather than live" (P. Turin: A, 2, 5). While these lines could be taken as idle threats, they strongly imply that interfering with the labor assigned to a temple could be a capital crime. No hallmarks of ritual are present, but the genre and fragmentary nature of the record means that we must be careful in concluding that there was no ritual aspect implied.

Similarly, Seti I decreed impalement for any keepers of cattle or keeper of hounds or herdsmen who stole cattle or hounds from the estate dedicated to the Osireion, or who caused offerings intended for the Osireion to be offered elsewhere (KRI 1:55-56). A lesser punishment is decreed for their superintendents and others who might commit the same or similar crimes. While we cannot determine why there was a difference in punishment for this particular group, it is clear that interfering with the cult was sometimes considered worthy of death and sometimes not. The description of impalement is completely lacking in ritual connotations. Likewise, there is an account of a $19^{\text {th }}$ Dynasty temple official who embezzled goods from the temple, for which he was sentenced to death (P. Mayer: A, 13B) using language bereft of any hint of ritual.

This clear evidence for a present yet inconsistent use of ritual slaying as a punishment for interference with the cult was not unique to the temple sphere. A similar set of circumstances is found when examining sources associated with the funerary cult. For example,



Figure 3. Depiction of Ankhtifi from his tomb. Photograph @ Alan Fildes, http:// alanfildes.com/plogger/?level=picture \&id=65 actually enacted is less the issue than is the idea that Egyptians from a variety of time periods felt that interrupting the funerary cult was a crime that should be met with ritual punishment, including ritual slaying (Muhlestein 2007; Muhlestein 2011: 26-29).

A decree created a relatively short time later (ca. 1760 B.C.E.) states that anyone, other than a functioning priest, who was found in a sacred funerary district was to be punished by burning (Stela Cairo JE 35256; Leahy 1989). The Abydos decree was inscribed on a boundary stone that was part of the processional route between the temple and a cemetery (fig. 4), providing a tangible link between the two sacred spaces we have been discussing. The entire text focuses on the sacred and ritual. Furthermore, burning was a punishment that often mimicked the burning of sacrifices and its ability to totally destroy a person lent itself to efficacy in both the mortal and postmortal realms, something that overlaps in purpose with ritual. Thus, while it is not explicit, the context of this inscription suggests there may have been ritual aspects to its death decree.

Later, Amenhotep III decreed burning for any who interfered with the funerary cult of one of his favorite courtiers (fig. 5; Varille 1968: 71). The text speaks of "the burning flames of the king" as the agent of death, including references to his Uraeus (the mythological fire-spitting snake that was on the king's brow on some of his crowns) and comparing it to the burning of Apophis (the great mythological chaos monster), a long-lived ritual. While it could be argued that this language meant that only Willems has convincingly argued that interference with Anktifi's funerary cult (fig. 3) was deemed punishable by being killed as part of the ritual procession for the god Hemen (Willems 1990). It is unknown if the punishment was ever actually employed, yet the First Intermediate Period inscription makes it clear that at least some felt that interference with funerary cults could be met with ritual slaying. Willems marshals an impressive array of inscriptions laden with ritual sacrificial terminology while speaking of death for interference with the funerary cult, such as having one's neck severed like a sacrificial bird's. Which, if any, of these textual threats were the supernatural could inflict the punishment, it is more likely that the language intentionally mythologized actions that could take place in the mortal realm (Muhlestein 2007). Ritual action would also affect more than one realm. That, coupled with comparing the potential punishment to a known ritual, suggests ritual trappings for the intended punishment.

In contrast, a number of other sources also indicate this kind of cultic interference was punishable by death, but carry no evidence of ritual aspects as a part of the punishment. While a number of texts speak of death for those who violate the tomb without 


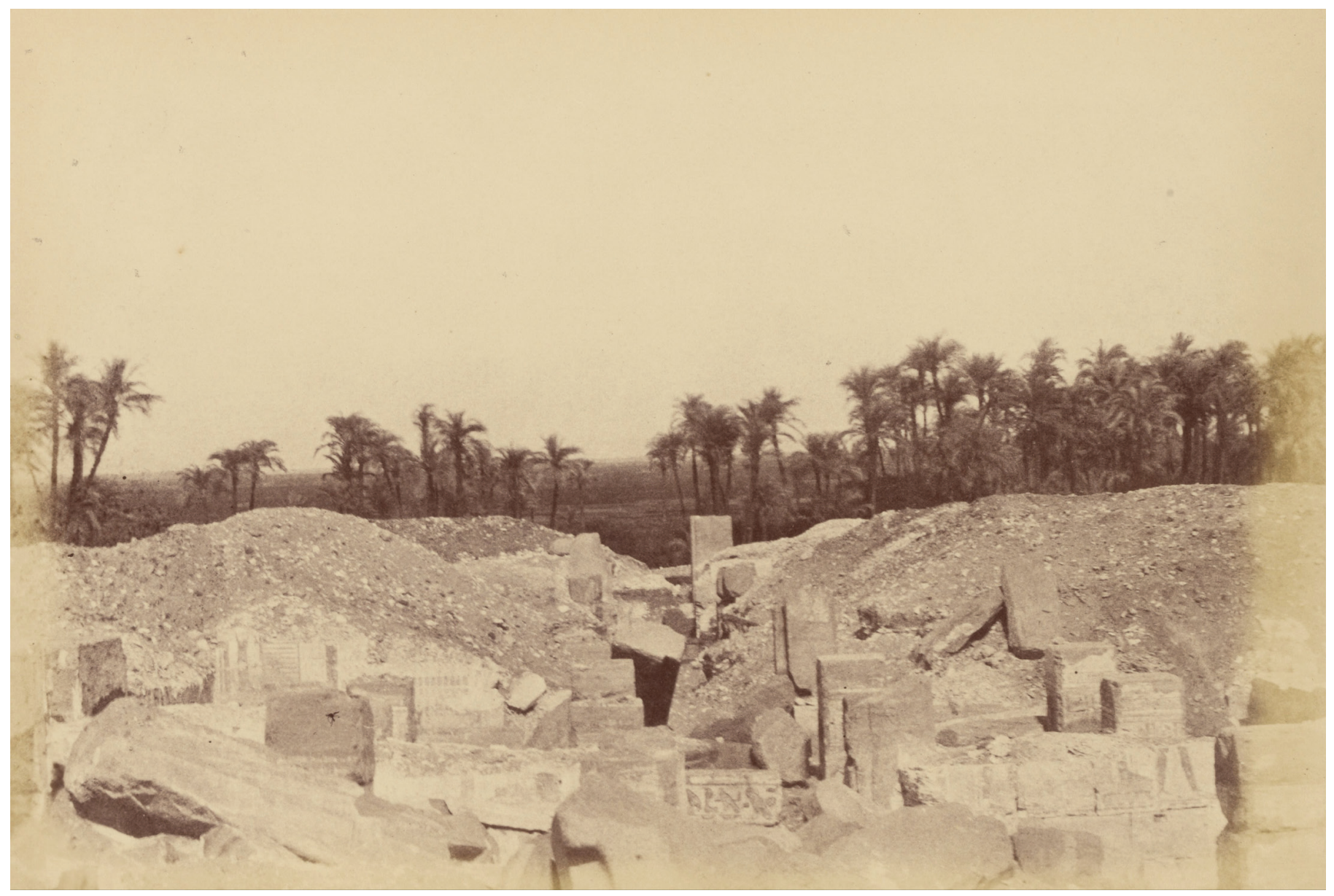

Figure 4 (above). The Small Temple at Abyodos, near the processional route to the cemetery where the boundary stela warning of being burned to death was set up. Photograph by Théodule Devéria.

Figure 5 (bottom left). Amenhotep son of Hapu, whose tomb and cult were protected by a decree issued by king Amenhotep III. Photograph by Jerzy Strzelecki. Figure 6 (bottom right). Hieroglyphic determinative depicting impalement. Drawing by Daniel McClellan, courtesy of the Brigham Young University Ancient Near Eastern Studies Program.
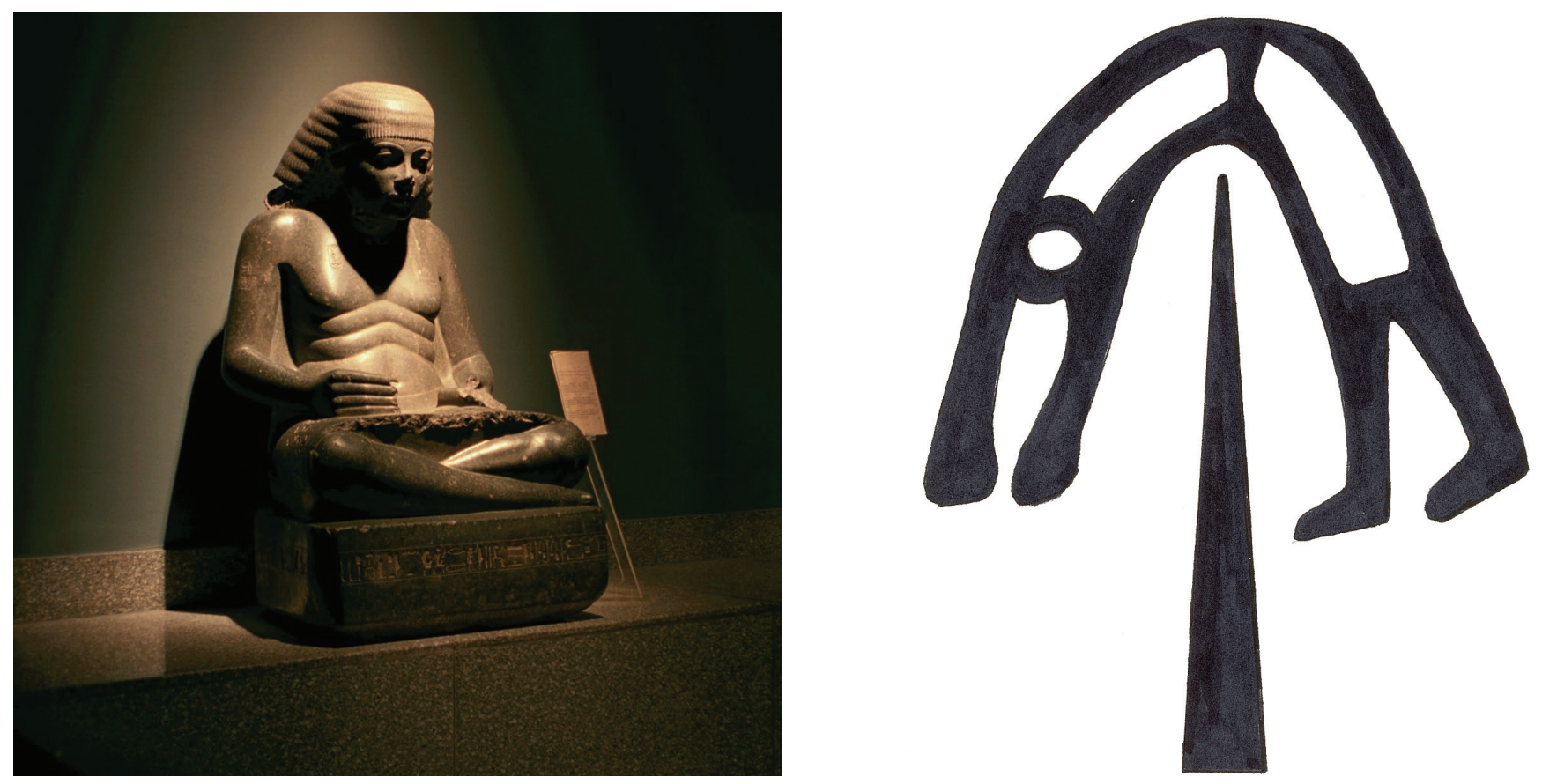

This journal was published by the American Schools of Oriental Research and is available on JSTOR at http://www.jstor.org/journal/neareastarch You may receive the journal through an ASOR membership or subscription. See http://www.asor.org/membership/individual.html for more information. 
using any ritual language (Urk. 4, 401, for example), probably the most prominent of these come from the Great Tomb Robbery documents from the end of the Ramesside era (ca. 1130 B.C.E.). These texts reveal that many of those accused of robbing the royal tombs were killed for their crimes and that it was apparently well known that a person could be put to death for robbing royal tombs (P. Mayer 13B; P. British Museum 10052: 4.9-10, 8.19-20). Additionally, some of those examined for tomb robbery were condemned for robbing non-royal tombs. The form of death decreed for the tomb robbers was consistently impalement (fig. 6). This particular form may have been more a result of a trend than having anything to do with the specific type of crime committed, for impalement seems to have been the preferred form of execution during the Ramesside era (Muhlestein 2011: 73). Yet it is worth noting that no texts associate impalement with ritualized language or actions.

Thus, like many of the inscriptions threatening death for interference with cult, none of the documents that speak of death for robbing the royal tombs use any ritual language. However, the documents available to us are descriptions of the trials, a mundane genre that is unlikely to describe any ritual trappings that may eventually accompany the actual decrees or enactments of the punishment. Even so, because impalement is not known to be associated with ritual and does not mimic other kinds of sacrifices in the way that stabbing and burning does, it seems quite likely that these executions were bereft of any ritual nature.

It is difficult to tell why some crimes against tombs were met with ritualized punishments while others were not. This is largely due to the paucity of records about trials and punishments. For the most part, ritual punishment was meted out for some kind of interference with the funerary cult besides damaging the tomb, though this is not universally true. Most of the non-ritualized punishments of which we are aware come in the wake of damaging or plundering tombs, though this is not universally true either. The most we can say is that interference with funerary cultic activity was the most likely kind of funerary desecration to be met with ritualized punishment.

There is other evidence for ritual violence associated with tombs, though not for interference with cult or damage to tombs. For instance, the famous Cannibal Hymn may actually refer to ritual slaying (Pyr 399b-406b). It has long been acknowledged

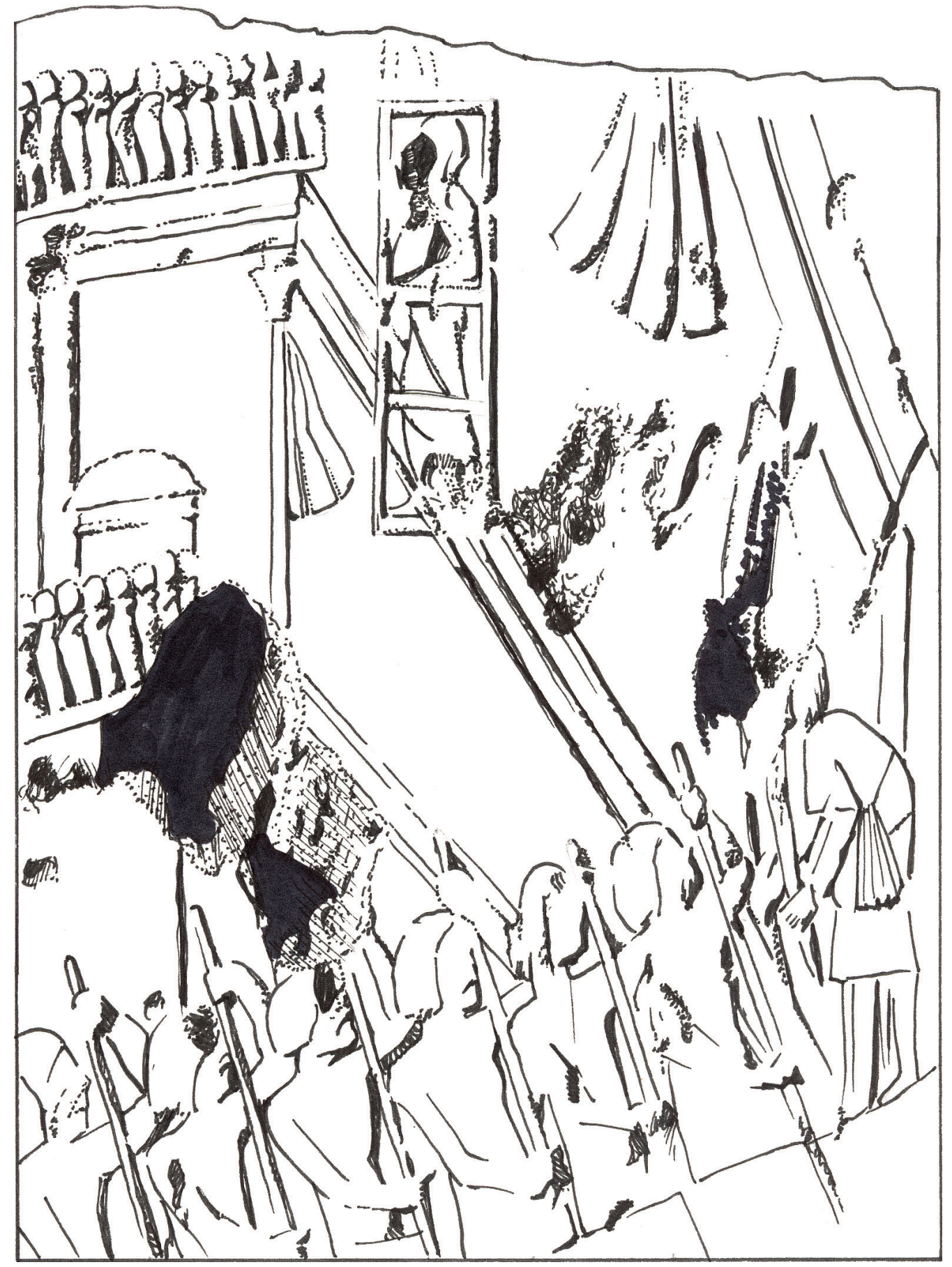

Figure 7. Relief from Karnak depicting a waterway procession under Tutankhamun with a caged prisoner hoisted for display. Drawing by Daniel McClellan, courtesy of the Brigham Young University Ancient Near Eastern Studies Program. 




Figure 8. Ramesses III slaying prisoners as depicted at Medinet Habu. Photograph by Mark Armstrong.

that the Pyramid Texts, including the Cannibal Hymn, were linked with ritual (Altenmüller 1977: 28; Assmann, 1990: 5-21). Eyre believes that a ritual was part of this spell at least as late as Dynasty 5 (Eyre 2002: 49, 55), though both he and Altenmüller do not believe any such ritual involved humans by the time of the Old Kingdom. Yet their arguments for this are somewhat circular and problematic (Muhlestein 2011: 22-24).

For example, the Cannibal Hymn took on a new life in the Coffin Texts, where in one version only cattle are mentioned as sacrificial victims (CT VI, 179a), though another version mentions that both human evil-doers and cattle were to be slaughtered (CT VI 181h). Because this Pyramid Text remained in use, but in a form that represented input from a new time period yet continued to have reference to human sacrifice, it bolsters the argument that this rite did indeed have an ongoing human component. Various other inscriptions align with this viewpoint. For instance, First Intermediate Period (ca. 2130-2010 B.C.E.) Assiut Tombs III and IV have inscriptions that say a desecrator will be burned, or cooked, with the criminals who seem to already be destined for that fate.

We find small bits of evidence for burning those who had committed heinous crimes throughout the entire period we are studying. Greater details about those crimes are available in the later sources.
For example, in the Petition of Petiese (a petition for redress from the early fifth century B.C.E.) two men were put to death for murder. Petiese felt that while others had been involved, the death of these two would suffice for the sake of justice, and that the others did not need to be burned in a brazier (P. Rylands IX, 12/16-17). Burning in a brazier carries strong ritual connotations, and in this case it was clear that the crime which demanded such action was murder. Similarly, a literary tale that dates somewhere between the $26^{\text {th }}$ Dynasty and the fourth century B.C.E. speaks of burning a murderer on a brazier at the door of the palace (P. Dem. Saq. I, 14/3-4). While the tale is fictive, it surely drew from situations with which its intended audience would be familiar, strongly suggesting that it was known that murderers were burned in a manner similar to other sacrifices, but perhaps at the palace rather than at a temple. These two sources make it clear that at least during later time periods, murder was punishable by burning, likely with ritual trappings.

While we cannot be certain, all of this suggests a long standing tradition of employing a cultic element when burning criminals. Because much of the known evidence stems from funerary contexts such as the pyramid and coffin texts or tomb inscriptions, this ritualized burning has a possible connection to the funerary cult, though some of the evidence for burning crimi- 
nals has nothing to do with tombs. While most of the evidence is silent about what crimes were deemed heinous enough to warrant burning to death, the Late Period evidence often describes murder as the crime which elicited this punishment. Thus, the burning of criminals seems to often carry a ritual aspect as well as a loose association with the funerary cult.

Overall, it is fairly clear that disruption of the funerary cult could be punished with ritual slaying. It is also clear that this was not always the case. Given our current data set, we cannot determine why some disruptions of the funerary cult were capital offenses and others were not, nor why some executions seem not to carry a ritual aspect while others do. It is also possible that some rituals associated with the tomb involved ritual slaying, and that criminals, most likely murderers, were the chosen victims for these rites. While this seems quite plausible based on the evidence at hand, we do not have enough information to determine anything but plausibility.

\section{Ritual Violence Associated with Rebellion}

Rebellion is the other category of crime with which ritual slaying was regularly associated. From the earliest to latest phases of ancient Egyptian history, rebellion was a capital crime. The concept of rebellion can take two forms. One is the uprising of conquered enemies rebelling against Egypt's hegemony; the other is the rebellion of an actual Egyptian. There are several ancient Egyptian words used to describe rebellion. Of the three most commonly used terms, sbi, bšt 3 , and $h 3 k$ $i b$, none are used exclusively for either Egyptians or foreigners who were controlled by Egypt. This makes it difficult to determine whether some forms of rebellion were made by people the Egyptians thought they controlled, or by people they did not control

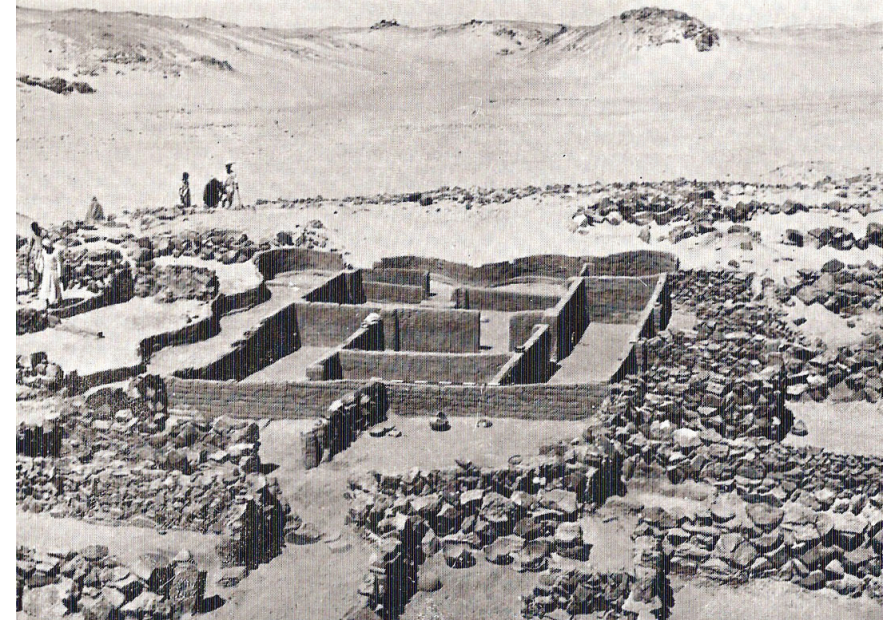

Figure 9. The Fortress of Mirgissa. Photograph by Jean Vercoutter, courtesy of Paul Guethner. festival (Urk. 4: 1408-13). Ramesses III records slaying captured Libyans using language that mirrored the descriptions of sacrificial birds (fig. 8; KRI 5, 25). Schulman has demonstrated strong evidence for many smiting scenes that were actually ritually enacted (Schulman 1988; Muhlestein 2011: 85-91). While this last issue is not fully agreed upon, it seems extremely likely that there were a number of ritual slayings of rebellious enemies by the kings of Egypt.

On the other hand, many captive enemies were killed without any reference to ritual aspects, such as when Akhenaten slew a great number of Nubian prisoners (Buhen Stela), or when Merneptah slew a number of Libyan and Nubian prisoners in two separate incidents and in two separate ways (KRI 4, 1: lines 1-8). None of the texts describing these incidents include any language that suggests ritual was involved. While it is clear that captured, rebellious enemies could be slain in a ritual way, it again does not seem this was always the case.

Most texts that discuss executing Egyptian rebels contain no ritual language. In contrast stands a text describing how Prince Osorkon dealt with a rebellion in Thebes. After quelling the rebellion, Osorkon called for many of the prisoners, bringing them "like a bunch of pinioned ones ( $m i \underline{h} t r \underline{d} n h w$ )." He then struck them

"like goats on the night of the Feast of the Evening Sacrifice in which braziers are lit $(m i$ 'rw grh ht ḩ3wy rkh ' hw im), like braziers at the going forth of Sothis ( $m i$ 'hw prt spdt). Every man was burned with fire at the place of his crime" (Bubastite Portal, Annals of the High Priest Osorkon, inscription of Year 11 of Takelot II: cols. 35-36). Such language makes it absolutely clear that these rebels were executed in a ritual context.

A less clear, but more prevalent, example stems from the execration ritual. Execration rituals were performed from the earliest to the latest phases but ideologically they still believed should be under their dominion. Even with such ambiguity, we can find some cases where it is clear that either Egyptians or those firmly in their control were found to be in rebellion and were ritually killed as a result.

From at least the Early Dynastic Period through the New Kingdom, there is a regular stream of evidence demonstrating a waterway procession of victory that included ritual display of conquered foreigners, including foreigners who were already thought to be under Egyptian control (Muhlestein 2005: 17375). Though some of these prisoners were displayed while alive (fig. 7), some, at least in the New Kingdom, had been slain as part of the ritual procession. Ritual slaughter of rebellious foreigners was not unique to waterway processions. For example, Amenhotep II reportedly slew seven princes at his coronation of Egyptian history, both in and outside of Egypt proper. While most of these rites employed inanimate objects in the place of the rebels they were aimed at, at least some, notably at Mirgissa (fig. 9) and Avaris, ${ }^{1}$ used actual humans as part of the rite (Ritner 1993: 163; Muhlestein 2008: 194-96). It is conceivable that dead bodies were used for the ritual rather than live victims, but this would be a radical departure from the live animals used in similar rituals and seems more like a modern sensitivity retrojected onto ancient Egypt than a possibility derived from evidence. While it is impossible to determine how often execration rites employed ritual slaying, and while we cannot tell if human victims were Egyptian rebels or occupied foreigners deemed rebellious, it seems certain that some execration rituals slew rebellious people. 


\section{Conclusion}

Our analysis of this topic is greatly hampered by insufficient data. Given the evidence at hand, it seems clear that while there were many crimes the ancient Egyptians thought merited capital punishment, and there were many ways in which that punishment could be inflicted, most did not include a ritual element. Yet this conclusion must remain tentative because it is equally likely that there were many ritual executions which did not leave behind a textual witness of their ritual nature. It could be argued that it is difficult to conceive of any execution in Egypt that would not have included some aspect that tied the action to a supernatural and religious context, thus making it at least partially ritualistic in its nature.

As can be seen from the examples above, in regards to the form of ritual punishments, impalement has no evidence for being a ritualized practice, while burning has a greater frequency of being described with ritual terms than other punishments. Burning also has a strong association with the crime of murder. Beyond this we cannot find a great deal of consistency as to what kind of punishment did or did not carry ritual trappings.

Greater clarity is possible regarding the kinds of crimes that were met with ritual execution. At least in the Late Period, and perhaps earlier, murder was often a capital crime, and the punishment could involve ritual aspects. Not all interference with cult was met with detectable ritual punishment, yet disturbing either the divine or funerary cult is the most likely crime to elicit ritual slaying as punishment. Concurrently, rebellion was not always met with detectable ritual response, yet it certainly could be. These are the two kinds of crimes that have a visible, and somewhat consistent, record of bringing about capital punishment dressed in ritual trappings. ?

\section{Note}

1. While some have recently disputed that the Avaris remains could not be execration because they lack signs of knife marks on the bones, this ignores the fact that one who is experienced cuts through the joints, not the bones, as has been noted by John Gee and others in personal communications.

\section{References}

Altenmüller, Hartwig. 1977. Bemerkungen zum Kannibalenspruch. 1-14. in Fragen an die altägyptische Literatur: Studien zum Gedenken an Eberhard Otto, eds. Jan Assmann, Erika Feucht, and Reinhard Grieshammer. Wiesbaden: Reichert.

Assmann, Jan. 1990. Egyptian Mortuary Liturgy. Pp. 1-37 in Studies in Egyptology, ed. S. Israelit-Groll. Jerusalem: The Magnes Press, The Hebrew University.

Buchberger, Hannes. 2006. Sesostris I. und die Inschrift von et-Tôd? Eine philologische Anfrage. Pp. 15-21 in Von reichlich ägyptischem Verstande. Festschrift für Waltraud Guglielmi zum 65 Geburtstag, eds. Karola Zibelius-Chen and Hans-Werner FischerElfert. Wiesbaden: Philippika.

Eyre, Christopher J. 2002. The Cannibal Hymn. A Cultural and Literary Study. Bolton: Liverpool University Press.

Muhlestein, Kerry. 2005. Death by Water: The Role of Water in Ancient Egypt's Treatment of Enemies and Juridical Process. Pp. 173-79 in L’Acqua nellantico Egitto: Vita, Rigenerazione, Incantesimo, Medicamento, eds. Alessia Amenta, Maria Michela Luiselli, and Maria Novella Sordi. Rome: L'Erma di Bretschneider.

- 2007. Empty Threats? How Egyptians' Self-Ontology Should Affect the Way We Read Many Texts. The Journal of the Society for the Study of Egyptian Antiquities 34: 115-30.

- 2008. Royal Executions: Evidence Bearing on the Subject of Sanctioned Killing in the Middle Kingdom. The Journal of the Economic and Social History of the Orient 51/2: 181-208.

- 2011. Violence in the Service of Order: the Religious Framework for Sanctioned Killing in Ancient Egypt. British Archaeological Reports International Series 2299. Oxford: Archaeopress.

Redford, Donald. B. 1987. The Tod Inscriptions of Senwosret I and Early $12^{\text {th }}$ Dynasty Involvement in Nubia and the South. Journal of the Society for Egyptian Antiquities 17: 36-57.

Ritner, Robert K. 1993. The Mechanics of Ancient Egyptian Magical Practice. Studies in Ancient Oriental Civilization 54.

Varille, Alexandre. 1968. Inscriptions concernant l'architecte Amenhotep, fils de Hapou. Cairo: Impr. de l'Institut francais d'archeologie orientale.

Willems, Harco. 1990. Crime, Cult and Capital Punishment, Mo'alla Inscription 8. Journal of Egyptian Archaeology 76: 27-54.



